\title{
Tantangan Pemerintah Daerah dalam Penyusunan Peraturan Daerah Desa Adat: Upaya dalam Penetapan Desa Adat di Indragiri Hulu, Riau
}

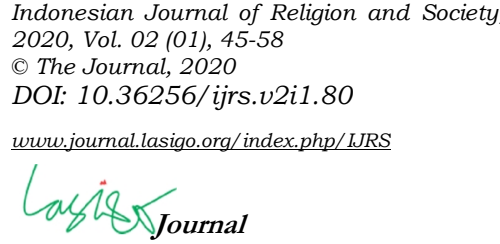

Article History

Received: February, 5th 2019

Revised: April, 30 2020

Accepted: May, $20^{\text {th }} 2020$

\section{Adli Hirzan}

Jurusan Antropologi dan Sosiologi, Fakulti Sains Sosial dan Kemanusiaan, Universiti Kebangsaan Malaysia, Malaysia

adli.hirzan@gmail.com

\section{Mimi Hanida Abdul Mutalib}

Jurusan Antropologi dan Sosiologi, Fakulti Sains Sosial dan Kemanusiaan, Universiti Kebangsaan Malaysia, Malaysia

mimi8ab@ukm.edu.my

\begin{abstract}
The objective of this article is to explain the challenges that occur in establishing customary villages. This research uses a qualitative approach with a case study design. This study uses thematic analysis, which aims to identify patterns and determine themes. Data collected using interviews and documentation. The results of the study found that there were four challenges in making regional regulations for the establishment of customary villages: first, the drafting period for the determination of customary villages was carried out in a short period. Second, not prioritizing socialization. Third, local wisdom is considered less critical for the sub-district government. Fourth, there is no follow-up from the local government to establish local regulations. The results of this study have implications for the miscommunication of local governments in understanding the village law no. 6/2014. As a result, local governments have not fully rearticulated the village law regarding the establishment of customary villages.
\end{abstract}

Keywords: Customary Law, Costumary Law Community, Customary Villages, Local Government, Rural Anthropology, Village Law

\begin{abstract}
ABSTRAK
Artikel ini bertujuan untuk menjelaskan tantangan yang terjadi dalam penyusunan peraturan daerah desa adat dalam upaya penetapan desa adat. Penelitian ini memakai pendekatan kualitatif dengan desain studi kasus. Penelitian ini menggunakan analisis tematik untuk mengidentifikasi pola dan menentukan tema-tema. Data dikumpulkan menggunakan wawancara dan dokumentasi. Hasil penelitian menemukan ada empat faktor tantangan dalam menyusun peraturan daerah pengakuan desa adat: rentang waktu penyusunan penetapan desa adat sangat singkat, tidak mengutamakan sosialisasi, kearifan lokal dianggap kurang penting bagi pemerintah kecamatan dan tidak ada tindak lanjut dari pemerintah kabupaten untuk menetapkan peraturan daerah. Hasil dari penelitian ini berimplikasi adanya indikasi terjadinya miskomunikasi pada pemerintah daerah dalam memahami undang-undang desa no. 6 tahun 2014. Akibatnya, pemerintah daerah tidak sepenuhnya mengartikulasikan kembali undang-undang desa tentang penetapan desa adat.
\end{abstract}

Kata Kunci: Hukum Adat, Masyarakat Hukum Adat, Desa Adat, Pemerintah Daerah, Antropologi Pedesaan, Undang-undang Desa

Corresponding Author

Name : Adli Hirzan

Email : adlihirzan@gmail.com 


\section{Pendahuluan}

Pada awalnya masyarakat hukum adat sudah ada dan berlangsung sangat lama dalam wilayah yang kemudian bernama Indonesia. Ia menjadi cikal bakal atas wujudnya suatu negara. Masyarakat hukum adat kemudian menjadi suatu entitas di negara Indonesia. Berbagai hak telah melekat pada masyarakat hukum adat dan hak itu merupakan esensi bagian dari hak asasi manusia (Noor, 2018). Saat ini hukum adat hanya dipandang sebelah mata dan bila perlu dipisah dari elemen komunitas masyarakat hukum adat. Padahal beberapa penelitian yang baru telah menemukan fungsi-fungsi dari hukum adat sangat berperan dalam kehidupan masyarakat. Pertama, hukum adat dapat menjadi alat kontrol sosial atau pengendali sosial. Kedua, hukum adat mampu menyelesaikan konflik di leveldaerah otonomi karena sifatnya yang dinamis. Ketiga, proses penyelesaian konflik secara adat seperti musyawarah dan mufakat selalu mengutamakan prinsip asas kekeluargaan. Relasi di antara hukum adat dengan hukum positif negara adalah hukum adat sebagai sumber utama yang diperlukan dalam penyusunan hukum positif karena hukum adat berisikan kandungan nilai-nilai (value), kaedah dan kearifan lokal (local wisdom) yang berlangsung pada masyarakat hukum adat (Warjiyati, 2018).

Pentingnya pemerintah daerah dalam menetapkan desa adat juga ditunjang oleh berbagai penelitian lain. Hukum adat dapat menyelesaikan masalah lebih berhati-hati melalui mufakat adat (Supian, Fatonah, \& Defrianti, 2018). Tampak bahwa peranan adat dalam menata kehidupan masyarakat sangat realistis hingga zaman globalisasi ini. Kearifan lokal dalam kapasitasnya juga mampu menyediakan resolusi konflik secara nonlitigasi dalam pertentangan tanah ulayat di perbatasan daerah lokal bahkan hingga ke perbatasan negara yang juga tentu mengutamakan asas kekeluargaan (Kalembang, 2018). Model resolusi konflik secara litigasi formal masih dianggap merugikan masyarakat hukum adat disebabkan pengabaian hak dan hukum adatnya (Farakhiyah \& Irfan, 2019). Dari berbagai penelitian itu menyatakan bahwa hukum adat masih mampu menyelesakan persoalan. Hukum adat juga mampu menata kehidupan masyarakat sangat realistis. Persoalan konflik tanah ulayat merupakan akibat dari mengabaikan hukum adat. Perusahaan dengan berbagai kiatnya selalu dimenangkan dalam berbagai kasus konflik namun meninggalkan persoalan bagi masyarakat adat.

Penguatan hukum adat sangat bergantung kepada kemampuan individu komunitasnya dalam menerapkan adat, tradisi (Salim, 2016) dan kejelasan identitas mereka. Identitas itu dapat ditandai dengan adanya tanah komunal (Wiguna, 2016) dan didukung oleh keberadaan rumah adat untuk membangun persatuan dan kesatuan. Identitas ini berhubungan pula dengan dinamika sosio-ekonomi, promosi kebudayaan, pemenuhan keperluan hidup dan ciri khas yang melekat pada diri mereka (Putri, Ramadhan, Sandya, Fazriyah, \& Maharani, 2019). Di satu sisi penguatan hukum adat dan identitas ini menjadi motivasi untuk pengakuan dan perlindungan dari tersusunnya peraturan daerah tentang desa adat. Di sisi lain penguatan hukum adat dan identitas ini memunculkan kekhawatirkan pada masyarakat yang kini tidak lagi homogen dan kehadiran perusahaan.

Fakta menyatakan hukum normatif yang dipakai tidak terlepas dari keberagaman hukum adat di Indonesia dan menjadi refleksi keberagaman masyarakat adat di Indonesia (Jayus, 2019). Dalam sejarahnya, kemudian pemerintah Orde Baru menerbitkan Undang Undang no. 5 tahun 1979 yang melahirkan penyeragaman format yang dipakai di Pulau Jawa dalam bentuk pemerintahan desa. Konsekuensi logis setelahnya, muncullah penyeragaman kepemimpinan adat dan norma hukum yang sama di Indonesia. Kepemimpinan adat misalnya pemimpin tidak lagi menjadi pusat otoritas (centre of authority) dan pusat ingatan (centre of memory) (E. Rahman, Azhar, \& Rohana, 2012). Zaman terus mengalir, kemudian pada masa reformasi pemerintah memberikan peluang dengan hadirnya Undang-Undang Desa no. 6 tahun 2014 (selanjutnya disebut UU Desa). Kampung-kampung di Indonesia yang masih memiliki adat atau hukum adat dapat menggunakan format pemerintahan adatnya masing-masing dengan berbagai ketentuan.Undang-undang ini memberi peluang yang signifikan bagi masyarakat hukum adat, terutama masyarakat hukum adat di Riau.

Di Riau saat ini sudah ada dua kabupaten yang berhasil menerbitkan peraturan daerah tentang desa adat, yaitu pertama di Kabupaten Siak yang menetapkan desa menjadi kampung adat. Kendala utamanya tidak melalui penelitian secara mendalam sehingga dari segi administratif ada aspek yang belum dipenuhi, seperti pemberian kode registrasi kampung adat, regulasi dalam penyelenggaraan pemerintahan adat, pengaturan serta penguatan kelembagaan adat yang ada (Alkadafi, Rusdi, Nasution, \& April, 2019). Kedua, 
kasus serupa juga terjadi di Kabupaten Rokan Hilir, persoalannya adalah ada desa yang memenuhi syarat namun menolak untuk ditetapkan sebagai desa adat dan sebaliknya ada desa yang belum memenuhi persyaratan tetapi memiliki keinginan kuat ditetapkan sebagai desa adat. Adanya berbagai persoalan seperti itu pemerintah daerah mengambil kebijakan menetapkan semua desa di kabupaten itu menjadi desa adat dengan tidak melalui penyaringan yang tepat dan tanpa melalui mekanisme sesuai dengan undang-undang (Suganda \& Amin, 2016).

Kelanjutan agenda UU Desa ini, pemerintah kabupaten di Riau bersama Lembaga Adat Melayu Riau tingkat kabupaten/kota melakukan identifikasi calon desa adat, antara lain di kecamatan Peranap tempat berdirinya wilayah adat Tiga Lorong (Fazar, 2014). Wilayah adat Tiga Lorong berdiri pada pertengahan abad ke-18 (1753-1765) di bawah masa kesultanan Indragiri XIII, Sultan Hasan Salahuddin Syah. Saat ini kawasannya berada di kecamatan Peranap dan kecamatan Batang Peranap (E. Rahman, Syam, \& Mardan, 2013). Berikut ini komposisi kedua kecamatan tersebut:

1. Kecamatan Peranap terdiri atas 2 kelurahan dan 10 desa antara lain; Kelurahan Peranap, Kelurahan Baturijal Hilir, Desa Baturijal Hulu, Desa Baturijal Barat, Desa Setako Raya, Desa Pauh Ranap, Desa Semelinang Tebing, Desa Gumanti, Desa Katipo Pura, Desa Semelinang Darat, Desa Pandan Wangi, dan Desa Serai Wangi.

2. Kecamatan Batang Peranap terdiri atas 10 desa antara lain; Desa Punti Kayu, Desa Pematang, Desa Pesajian, Desa Selunak, Desa Pematang Benteng, Desa Suka Maju, Desa Sencano Jaya, Desa Sungai Aur, Desa Peladangan, dan Desa Koto Tuo.

Gambar 1. Peta Administrasi Kabupaten Indragiri Hulu

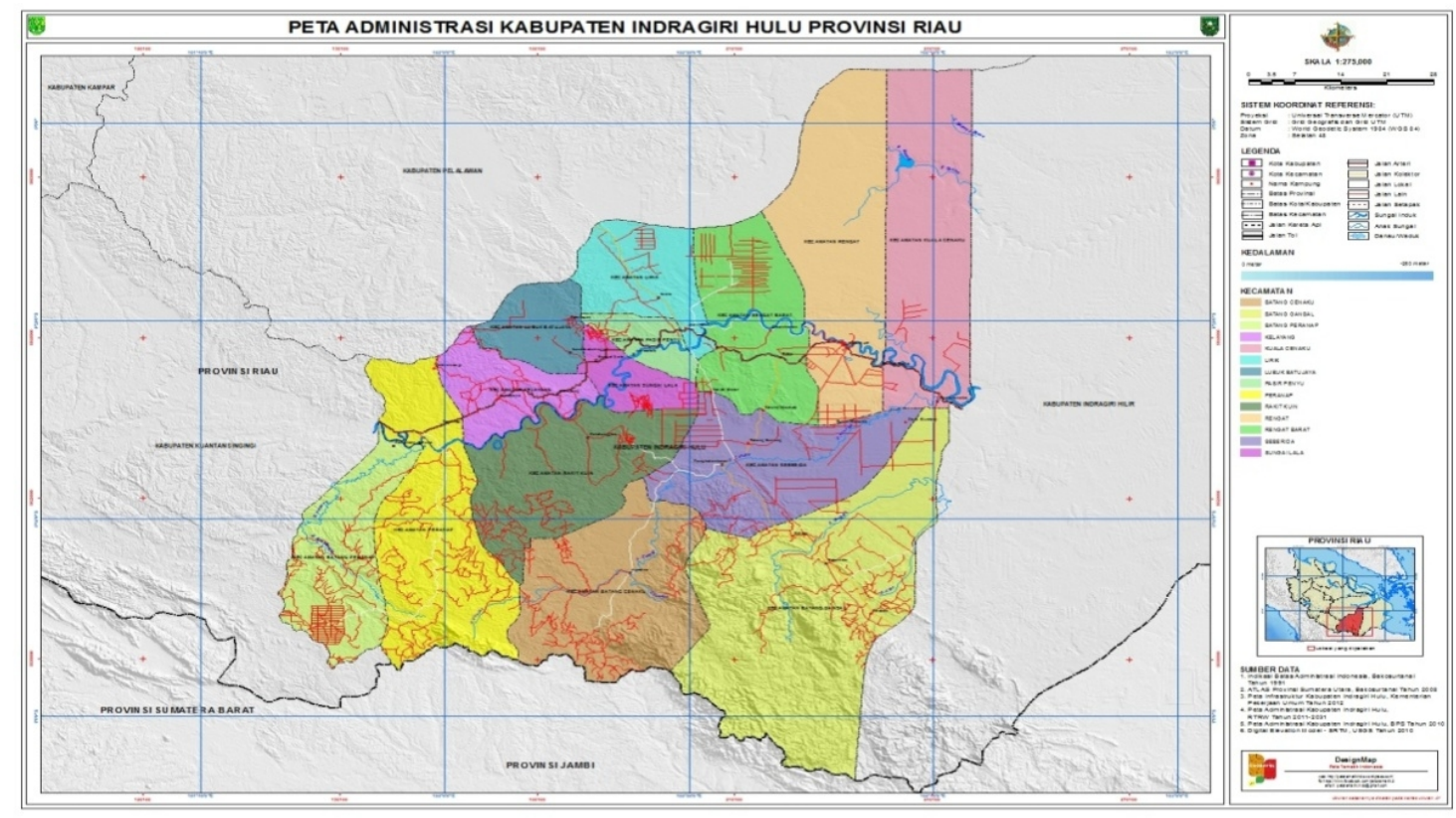

Sumber: Dishut.inhukab.go.id (2020)

Dari gambaran di atas dapat dikatakan bahwa peranan hukum adat dalam membina masyarakat masih menjadi satu unsur penting di kehidupan masyarakat. Kekeliruan yang pernah terjadi pada zaman Orde Baru di Indonesia dapatdiperbaiki dengan berdirinya desa adat. Kemunculan UU Desa tahun 2014 memberi harapan baru bagi revitalisasi pemerintahan adat. Penghulu dan pemangku adat sebagai perangkat desa dapat mengurus sendiri corak pemerintahan adat di wilayah mereka. Pemerintah daerah sebagai pemerintah yang reaktif terhadap kebijakan ini harus mampu memfasilitasi semua keperluan untuk menegakkan adat di desanya. Pihak kabupaten pada pemerintah eksekutif tentu saja menemukan berbagai hambatan yang terjadi di wilayahnya untuk menetapkan desa adat. Kembalinya kepada pemerintahan adat ini sebagai upaya menghadirkan kembali identitas daerah dan membantu meringankan kerja pemerintah daerah dalam menangani berbagai masalah di desanya masing-masing. Artikel ini bertujuan untuk mendeskripsikan 
tantangan yang terjadi di pemerintah daerah dalam menetapkan desa adat di Indragiri Hulu, Riau.

\section{Kerangka Teori dan Konsep}

Teori kebijakan publik untuk menjelaskan segala tantangan Undang Undang Desa yang berkaitan dengan desa adat yang dihadapi di tingkat pemerintah daerah dalam membentuk peraturan daerah tentang desa. Anderson (1979:3) menjelaskan bahwa kebijakan publik sebagai kebijakan yang ditetapkan oleh badan-badan dan aparat pemerintah. Sedangkan menurut Dye (1981), kebijakan publik adalah apapun pilihan pemerintah untuk melakukan atau tidak melakukan (public policy is whatever government choose to do or not to do). (Winarno, 2016). Kebijakan publik menjadi sangat luas karena mencakup sesuatu yang tidak saja dilakukan oleh pemerintah ketika pemerintah menghadapi suatu masalah publik.Kebijakan publik tidak hanya dipengaruhi aktor dan faktor dari internal pemerintah saja tetapi juga dapat dipengaruhi oleh para aktor dan faktor dari luar pemerintah. Sementara itu, pendekatan yang digunakan untuk menganalisis faktor-faktor apa yang menjadi tantangan adalah pendekatan kelembagaan (institutionalism). Pendekatan model ini memfokuskan peneliti pada apa yang seharusnya dilakukan oleh elemen dalam struktur birokrasi pemerintah, dengan cara melihat grafik dari mekanisme kerja sesuai dengan aturan yang berlaku (Taufiqurakhman, 2014). Anderson dalam (Winarno, 2016) menyatakan bahwa pendekatan kelembagaan bukanlah pendekatan yang sempit atau bersifat deskriptif, karena seorang peneliti dapat menanyakan hubungan-hubungan yang terjadi antara aturan-aturan kelembagaan dengan substansi kebijakan publik. Seorang peneliti juga dapat menyelidiki hubungan-hubungan ini dalam suatu bentuk yang bersifat sistematik dan komparatif.

Unsur (variabel) masyarakat hukum adat dalam artikel ini menjadi sangat penting karena sebagai unit analisis pada kebijakan publik. Menurut Idris (2000) dalam (Idris, Apriani, \& Erlina, 2019) konsep masyarakat hukum adat adalah sebagai masyarakat yang terorganisasikan dalam kemasyarakatan yang memiliki satu wilayah tempat tinggal, mempunyai pemimpin, kekayaan komunal, serta hidup bersama antar individu masyarakat lainnya. Dijelaskan lebih rinci oleh Bushar (2003) dalam Idris (et al., 2019) bahwa kehidupan bersama masyarakat hukum adat dikaitkan dengan faktor silsilah keturunan (genealogy) atau faktor daerah wilayah yang sama (territory) maupun gabungan kedua faktor yang ada. Berikutnya, Naim (2008) dalam (Idris et al., 2019) juga menjelaskan masyarakat adat memerlukan satu kontrol sosial yaitu hukum adat untuk menjaga keberlangsungan kehidupan masyarakatnya yang bisa diterima sekaligus juga berkembang sebagai tertib sosial dan tertib hukum. Jadi, masyarakat yang terikat dengan hukum adat serta dapat diterima dan berkembang di dalam komunitasnya sebagai pedoman dalam kehidupan bermasyarakat dinamakan dengan masyarakat hukum adat.

Beberapa penelitian terdahulu menjelaskan perkembangan integritas hukum adat dalam hukum positif negara. Agus (2017) menyatakan adanya aturan hukum adat yang bertolak belakang dengan hukum negara disebabkan negara lebih mengutamakan pembangunan dan cenderung membela perusahaan yang melakukan investasi di kawasan masyarakat hukum adat sudah lama menempati wilayah tersebut tanpa memikirkan dampak sosial, sementara hak-hak tradisional yang melekat pada masyarakat hukum adat seringkali terabaikan. Namun, revitalisasi peradilan adat dalam sistem peradilan berkaitan dengan pembangunan hukum di Indonesia serta menjadi bentuk proteksi kepada masyarakat hukum adat yang selaras dengan Rencana Pembangunan Jangka Panjang Nasional Tahun (RPJPN) 2005-2025 (E. Rahman, 2018). Sementara itu, di Sumatera Utara, beberapa substansi hukum adat bahkan diadopsi dalam berbagai putusan hukum oleh Mahkamah Agung seperti hukum keluarga, perkawinan, perceraian, waris, tanah dan sebagainya (Pohan, 2018). Sosialisasi nilai-nilai religius Islam juga kerap dilakukan dan sangat terbantu oleh majelis adat di Aceh, namun pemerintah daerah belum maksimal dalam membina (Hamdi, 2018). Kasus di Provinsi Jambi, peranan hukum adat masih dipakai dalam menyelesaikan masalah pada masyarakat yang bersifat kekeluargaan, bahkan hukum adat digunakan sebagai pertimbangan oleh penegak hukum formal negara seperti polisi, jaksa, serta hakim pengadilan (Rahman, 2018). Sementara dalam (Hamamah \& Sarip, 2019) menemui kesulitan untuk menggali lebih dalam hukum adat melalui lembaga adat desa disebabkan kapasitasnya yang rendah serta kurangnya pembinaaan dari pemerintah daerah. Besarnya peranan pemerintah daerah dalam membangun masyarakat melalui hukum adatnya perlu dikaji secara mendalam. 


\section{Metode Penelitian}

Penelitian ini menggunakan pendekatan kualitatif. Burns and Grove (2009) dalam Mohajan (2018) berpendapat bahwa pendekatan kualitatif adalah suatu pendekatan yang sistematis dan subjektif untuk menyorot dan menjelaskan pengalaman hidup sehari-hari dan juga untuk lebih lanjut memberikan makna yang tepat pada hasil penelitian. Penelitian ini dilakukan di kecamatan Peranap, kabupaten Indragiri Hulu dengan jumlah informan berjumlah 15 orang dengan menggunakan metode wawancara semi-berstruktur, observasi dan pengumpulan dokumen yang berkaitan pada tahun 2014-2017. Pensampelan bertujuan dipilih untuk menentukan informan berdasarkan kriteria tertentu seperti masyarakat hukum adat dan siapa-siapa saja yang terlibat dalam proses penetapan desa adat. Informan yang menjadi sampel penelitian terdiri dari kepala bidang Dinas Pemerintahan Desa Kabupaten Indragiri Hulu, Camat Peranap, Pengurus Lembaga Adat Melayu Riau kabupaten, dan beberapa kepala desa. Jenis desain penelitian ini adalah berbentuk studi kasus. Creswell mendefinisikan studi kasus sebagai bentuk yang membolehkan peneliti mengeksplorasi lebih dalam suatu program, suatu peristiwa, suatu aktifitas, suatu proses, atau satu atau lebih dari satu individu (Creswell, 2009).

Gambar 2. Flowchart (Bagan Alir) Triangulasi Sumber Data Wawancara

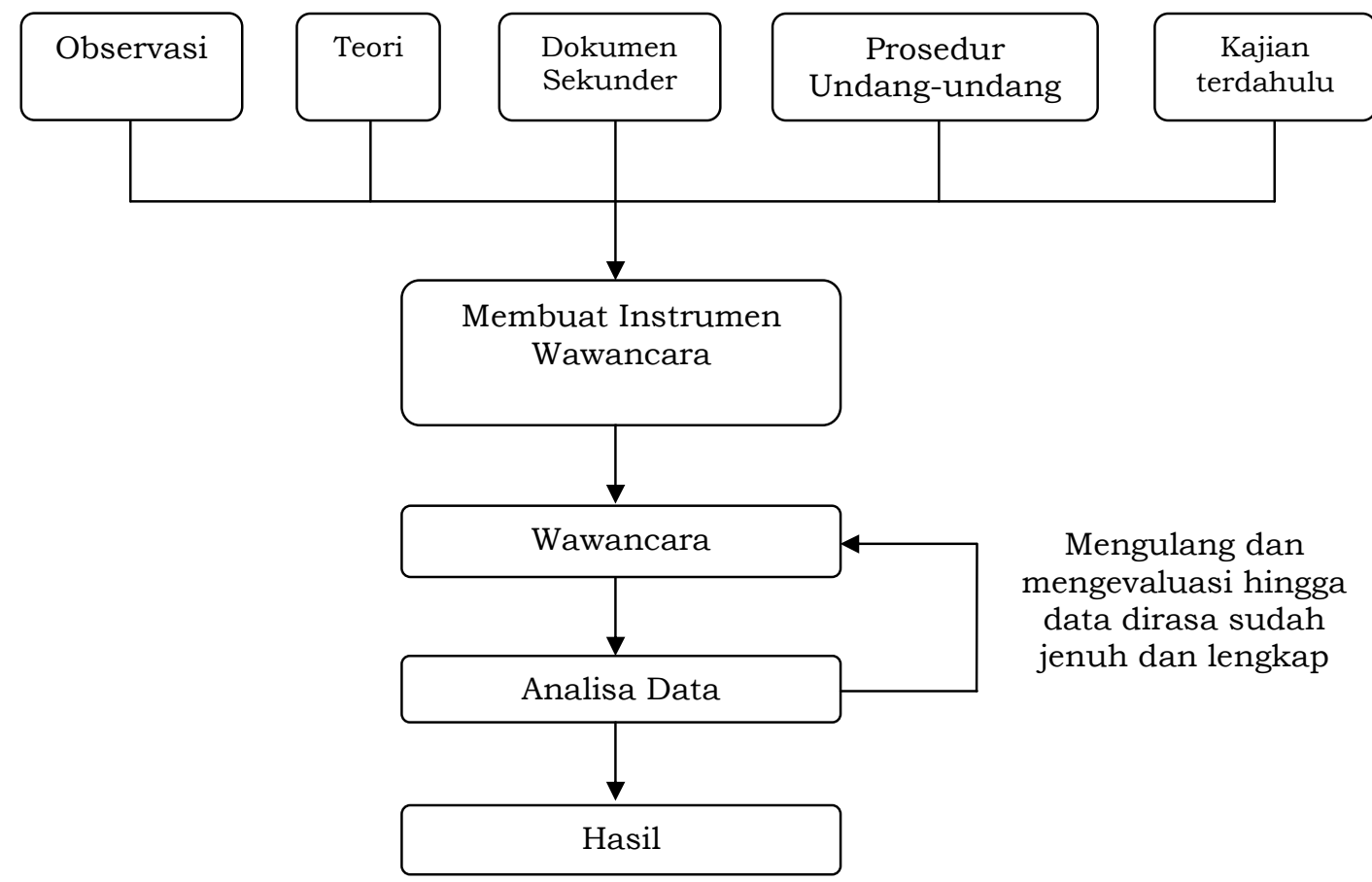

Diadopsi dari Denzi (1970) dalam Fusch, Fusch, \& Ness, (2018)

Pada akhirnya, penelitian ini menggunakan metode analisis tematik karena metode ini dianggap paling tepat untuk setiap penelitian yang berusaha untuk menemukan temuantemuan menggunakan interpretasi si peneliti (Alhojailan, 2012). Menurut Braun \& Clarke (2006) dalam (Heriyanto, 2018) bahwa analisis tematik adalah suatu cara untuk menganalisa data dengan tujuan untuk mengidentifikasi pola (pattern) dan menemukan tema melalui data yang telah dikumpulkan oleh seorang peneliti. Teknik ini dianggap sangat efektif apabila sebuah kajian bermaksud untuk mengupas secara rincidata berbentuk kualitatif, berguna untuk menemukan hubungan pola-pola dalam suatu fenomena serta menjelaskan sejauh mana sebuah fenomena terjadi melalui pandangan si peneliti (Fereday \& Muir-Cochrane, 2006). Tambahan lagi, Holoway \& Todres (2003) mengatakan bahwa analisis tematik ini juga sebagai dasar untuk kepentingan dalam menganalisa penelitian yang bersifat kualitatif. Tahapan dalam teknik ini serupa dengan teknik analisa kualitatif lainnya yaitu mula-mula peneliti harus memahami data yang sudah diperoleh, lalu menyusun kode, dan dilanjutkan dengan mencari tema (Heriyanto, 2018). Selanjutnya, triangulasi data digunakan sebagai proses verifikasi yang 
meningkatkan validitas data dengan menggabungkan beberapa sudut pandang dan metode. Dalam ilmu sosial, hal ini mengacu pada kombinasi dua atau lebih teori, sumber data, metode, atau peneliti dalam satu studi tentang fenomena tunggal untuk menyatu pada konstruksi tunggal, dan dapat dilakukan dalam kedua studi seperti kuantitatif (validation) dan kualitatif (inquiry).

Sepanjang pelaksanaan analisis data, peneliti juga melakukan triangulasi. Triangulasi adalah proses verifikasi yang meningkatkan validitas data dengan menggabungkan beberapa sudut pandang dan metode (Yeasmin \& Rahman, 2012). Dalam ilmu sosial, hal ini mengacu pada kombinasi dua atau lebih teori, sumber data, metode, atau peneliti dalam satu studi tentang fenomena tunggal untuk menyatu pada konstruksi tunggal, dan dapat dilakukan dalam kedua studi seperti kuantitatif (validation) dan kualitatif (inquiry). Sebenarnya, ada banyak pendekatan berbeda untuk 'triangulasi' dan ada mengartikulasikan pendukung untuk setiap pendekatan. Denzin (1970) membedakan empat bentuk triangulasi. Triangulasi sumber data adalah mengambil informasi data dari sejumlah berbagai sumber perolehan data untuk membentuk satu badan data. Dapat dilihat jelas pada gambar 2 berikut ini, peneliti mulai melakukan observasi pada tahun 2014, memahami teori, dokumen berkaitan, prosedur undang-undang, serta kajian terdahulu untuk menyusun soal instrumen wawancara. Dilanjutkan dengan wawancara pada tahun 2017 dan hasil wawancara dapat langsung dianalisis. Selama analisis, soal instrumen terus berkembang. Ini bagus dilakukan sebagai upaya mengeksplorasi fenomena lebih jauh lagi dan terperinci. Wawancara dilakukan berulang-ulang kepada 15 orang informan kajian sebagai teknik triangulasi hingga memperoleh data yang lengkap dan jenuh.

\section{Tantangan Penyusunan Peraturan Daerah Desa Adat 4.1. Waktu Penetapan Desa Adat yang Relatif Singkat}

Setelah keluarnya UU Desa di tahun 2014, masyarakat hukum adat memang mendapatkan tempat yang khusus di bagian Undang Undang tersebut. Tetapi dalam amanahnya pengakuan tidak diberikan seluas-luasnya kepada masyarakat hukum adat. Merujuk pasal 116 ayat 3 bahwa penetapan desa adat dilakukan paling lama 1 tahun setelahUndang Undang no. 6 Tahun 2014 diterbitkan. Pemberian waktu 1 tahun ini menjadi tantangan bagi pemerintah daerah untuk menggesa pembuatan peraturan daerah penetapan desa adat atau menjadi kegagalan suatu pemerintah daerah karena waktu yang tidak mencukupi.Mulai dari proses menginventarisir identitas adat, eksistensi adat, harta adat hingga kepada terbitnya peraturan daerah. Untuk melihat efek daripada kebijakan pusat berkenaan masa yang diberikan kepada pemerintah daerah untuk menetapkan desa telah dikonfirmasi kepada Kamaruzaman (47 tahun) sebagai kepala bidang Dinas Pemerintahan Desa kabupaten Indragiri Hulu.

Menurutnya, pemerintah daerah telah meminta bantuan kepada pihak kecamatan untuk melakukan inventarisir.Namun,waktu yang terbatas itu, pemerintah daerah belum menerima usulan dari kecamatan calon desa adat yang teridentifikasi dan layak memenuhi syarat dan kriteria tertentu sebagai desa adat.Jadi, pemerintah daerah telah melakukan koordinasi kepada pemerintah kecamatan dalam persoalan identifikasi calon desa adat.Pernyataan ini juga telah dikonfirmasi di tingkat kecamatan yakni Azwarno (55 tahun).Azwarno mengatakan bahwa perangkat desa sudah mengusulkan, tetapi dalam waktu yang singkat tidak dapat disiapkan untuk diajukan ke pemerintah kabupaten. Ia juga mengakui kesulitan terhadap pemahaman bentuk desa adat yang diinginkan Undang Undang karena tidak ada sosialisasi sampai kepada masyarakat.

\subsection{Tidak Mengutamakan Sosialisasi Pedoman Penetapan Desa Adat}

Sejak UU Desa ini diterbitkan persoalan dasarnya selain waktu seperti data di atas, juga sosialisasi yang relatif minim. Awalnya sosialisasi dilakukan oleh legislatif nasional bersama pemerintah pusat, namun UU Desa 2014 merupakan undang-undang yang harus disebarluaskan hingga ke tingkat terendah yaitu desa atau kelurahan. Merujuk Undang Undang no. 12 tahun 2011 tentang pembentukan peraturan perundang-undangan, pada pasal 90 ayat 2 juga mengamanatkan peranan Dewan Perwakilan Daerah (DPD) dalam menyebarluaskan undang-undang yang berkaitan dengan otonomi daerah. UU Desa adalah undang-undang yang memberikan otonomi seluasnya kepada desa untuk mengurus rumah tangganya sendiri.Otonomi desa diberikan seluas-luasnya kepada desa adat yang memiliki kekayaan seperti tanah ulayat, tanah hayat,grand sultan, dan lain sebagainya. 
Dalam proses penyebarluasan UU (sosialisasi UU) harus ditinjau juga informasi materi Undang Undang tersebut adakah sudah sampai kepada objek Undang Undang yaitu lapisan pemerintah daerah dan masyarakat desa. Bagian ini telah ditemukan keadaan realitas yang terjadi di masyarakat bahwa apa yang menjadi cita-cita dalam undang-undang ini belum sampai kepada masyarakat desa (wawancara bersama Kamaruzaman, 47 tahun).

Pihak pemerintah kabupaten mengakui peluang untuk masa sosialisasi UU sangat singkat. Sosialisasi yang dilakukan baru sebatas garis besar berkaitan kewenangan desa. Namun waktu itu, pemerintah masih menerima usulan lebih lanjut. Sementara itu, Sabawaihi (39 tahun) dan Demsuandi (41 tahun) sebagai Kepala desa Baturijal Barat dan Baturijal Hulu keduanya mengakui waktu yang terbatas. Sosialisasi UU Desa 2014 seperti sumber pendapatan desa, alokasi dana desa dari APBD (Kabupaten) dan ABPN (Pusat), tetapi sosialisasi yang khusus berhubungan dengan mekanisme atau prosedur penetapan desa adat tidak pernah didengar dan diketahui oleh masing-masing pemerintah desa. Mereka juga menyatakan bila ada sosialisasi pasti akan disambut baik dan langsung mengusulkan kepada pemerintah kabupaten. Hal ini beralasan karena di desa mereka memenuhi desa adat, seperti memiliki hukum adat, wilayah adat, dan masyarakat adat. Pada tahun 2004, kedua pemerintah desa ini pernah mengeluhkan bahwa hutan yang juga merupakan hak ulayat mereka diserahterimakan kepada perusahaan swasta (private). Sehingga pada tahun 2009 sebelum munculnya UU Desa tahun 2014, kedua pemerintah desa ini juga pernah berusaha untuk mengusulkan kepada pemerintah kabupaten untuk membuat peraturan daerah berhubungan adat mereka secara legal yang sesuai dengan peraturan dan perundang-undangan, tetapi tidak ditanggapi pemerintah kabupaten.

\subsection{Pengabaian Terhadap Kearifan Lokal di Tingkat Kecamatan}

Proses penetapan desa adat tidak sesederhana yang dibayangkan banyak pihak, karena diperlukan berbagai faktor, antara lain faktor dukungan. Peranan pemerintah kecamatan, misalnya sebagai pihak yang lebih paham dan mengenal karakteristik demografi masyarakat di desa yang dipimpinnya perlu lebih fokus dan serius. Sejalan dengan UU no. 23 tahun 2014 tentang pemerintah daerah bahwa pemerintah kecamatan selain sebagai penyelenggara pemerintah di tingkat kecamatan, juga mempunyai tanggung jawab sebagai penyedia pelayanan publik dan tugas dalam pemberdayaan masyarakat desa. Sikap penyelenggara pemerintah kecamatan yang skeptis terhadap desa adat menghambat pendirian desa adat. Azwarno menilai adat dan tradisi tidak perlu perlu dipertahankan, hukum adat masyarakat desa sudah longgar. Azwarno sebagai Camat Peranap yang meskipun lahir dan dibesarkan di wilayah Tiga Lorong memperlihatkan sikap yang antipati terhadap adat yang pada gilirannya mempengaruhi kualitas dukungan penetapan desa adat.

Berbeda dengan penjelasan kedua Kepala Desa di bawahnya, Camat Peranap malah menilai desa di wilayah kekuasaannya tidak lagi terikat dengan adat istiadat. Pernyataan Camat Peranap ini tidak berdasar dan sangat emosional, karena tidak ada usaha pihak Kecamatan untuk melakukan inventarisir desa adat yang ada di Kecamatan Peranap sesuai mekanisme atau aturan dan progres. Pernyataan Camat Peranap secara langsung menunjukkan lemahnya dukungan pemerintah kecamatan dalam memperjuangkan desa adat. Menurutnya, penetapan desa adat tidak memberikan dampak terhadap perekenomian dan pelestarian kebudayaan dan bukan merupakan unsur penting dalam masyarakat. Pernyataan Camat Peranap ini berbeda berdasarkan observasi yang dilakukan sewaktu acara adat Tiga Lorong dan pengumpulan dokumen yang berkaitan telah menjelaskan sesuatu yang menunjukkan eksistensi masih terjaga utuh adat-istiadat Tiga Lorong ini. Dari wawancara dengan Lembaga Adat Melayu (LAM) Kecamatan Peranap diketahui narasumber ini memiliki hubungan disharmonis dengan pemerintah Kecamatan Peranap yang merupakan kelanjutan dari hubungan disharmonis Bupati dengan LAM kabupaten.

Pada gambar 3, merujuk E. Rahman et al., (2013) menjelaskan anugerah yang diperoleh berbentuk bendera dari Kerajaan Indragiri. Penghulu Jo Mangkuto memperoleh anugerah dua bendera kebesaran yaitu bendera warna hitam anugerah dari Raja Kuantan sebagai lambang kekuasaan penghulu adat dengan wilayah kekuasaan di Rantau Kuantan, bendera berwarna merah dari Sultan Indragiri sebagai lambang panglima besar atau panglima perang Indragiri. Danang Lelo juga diberi anugerah oleh Raja Indragiri dengan bendera hitam, sementara Lelo Dirajo mendapat anugerah bendera putih.Masyarakat Tiga Lorong juga menggunakan Tembo Tiga Lorong sebagai sumber undang-undang adatnya dalam semua aspek kehidupan. 
(3)

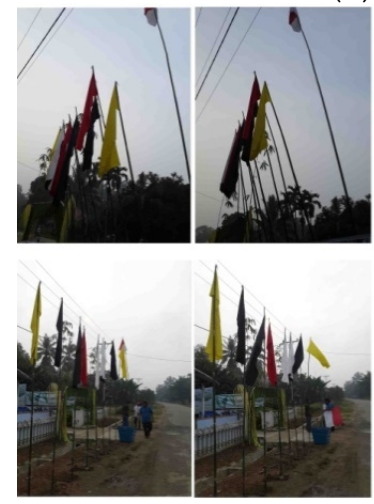

Sumber: Dokumentasi Peneliti
(4)
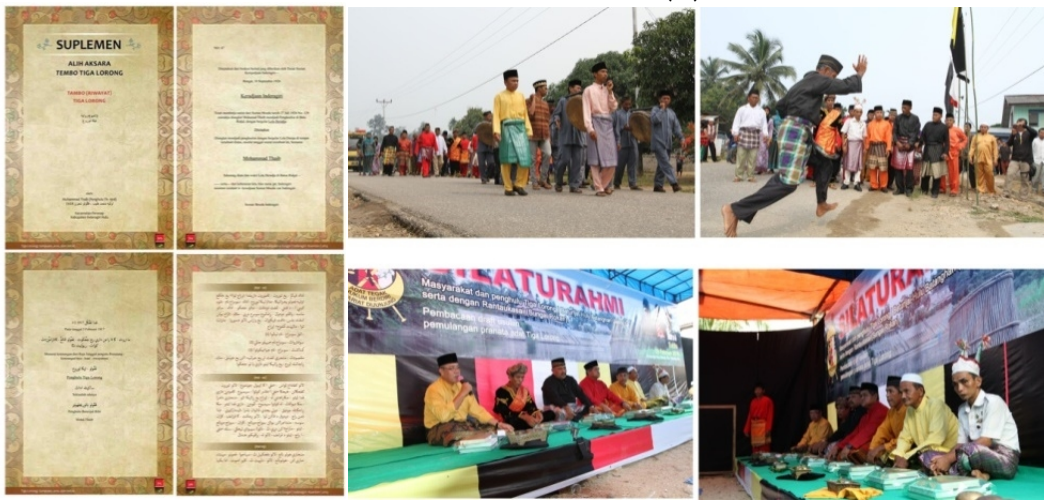

Gambar 4 juga menjelaskan bahwa masyarakat adat Tiga Lorong beramai-ramai dengan Penghulu Adat Tiga Lorong Baturijal Hulu, pemangku adat Baturijal di Hulu Batanghari (Jambi), dan Rantau Kasai (Sungai Rokan) melakukan acara silahturahmi pada 8 Februari 2014 di Danau Baturijal Barat Inderagiri Hulu. Pertemuan silahturahmi yang syarat dengan nilai historis, yaitu sejak nenek moyang mereka terpisah pada abad ke-17 lalu itu membincangkan dan menyusun langkah-langkah dalam upaya pemulangan kembali pranata adat ke pangkuan masyarakat adat. Silahturahmi dan pemulangan pranata adat adalah suatu bentuk perjuangan pimpinan adat (penghulu) demi kemaslahatan masyarakat adatnya dengan bekerja sama dengan pemerintah daerah. Pertemuan silaturahmi adat itu diprakarsai oleh penghulu Tiga Lorong, yaitu Datuk Sangguno dari Pulau Hulu Batanghari, Datuk Bandaro Raden Orang Godang Lareh dari Baturijal Hulu Batanghari, Batin Gajian Talang Gedabu (suku asli Talang Mamak), Datuk Danang Lelo Pematang, Datuk Jo Mangkuto Baturijal Hulu, Datuk Lelo Derajo Baturijal Hilir, dan H. Darman gelar Kahlifah Arif dari Rantau Kasai-Sungai Rokan. Saat itu, acara diawali dengan penyambutan saudara tua, yaitu orang Tiga Lorong dari Baturijal Dharmasraya. Penyambutan itu dilakukan arak-arakan dengan Dikir Bardah mulai dari Masjid Al-Falah ke Rumah Jo Mangkuto yang kemudian disambut dengan aksi silat adat. Bupati Indragiri Hulu juga hadir yang diwakili Harman Harmaini, SH (Wakil Bupati) sebagai representasi pemerintah daerah dan memberi pengarahan tentang peluang wilayah Tiga Lorong menjadi desa adat.

Wakil Bupati saat acara itu menunjukkan sikap yang kuat untuk mendukung wilayah Tiga Lorong menjadi desa adat dalam pidato kunci acara itu. Pemerintah daerah sadar bahwa kapasitasnya dalam menyelesaikan persoalan-persoalan yang terjadi dalam wilayah adat tersebut masih belum maksimal, terutama hutan ulayatnya. Pada pertemuan itu juga dibacakan Tembo Jo Mangkuto Baturijal Dharmasraya, Tembo Tiga Lorong. Tembo dari masyarakat Tiga Lorong Rantau Kasai Sungai Rokan serta pembacaan draft usulan pemulangan pranata adat di Tiga Lorong oleh peneliti budaya Junaidi Syam. Perkara penting dalam pertemuan itu, menurut Junaidi adalah pemulangan pranata adat ini sendiri merupakan pengusulan yang diprakarsai tiga penghulu yaitu Danang Lelo, Jo Mangkuto, Lelo Dirajo bersama-sama dengan Menti, Datuk Dupati, Tenganai Besar dan Tenganai Rumah yang kemudian didukung oleh anak kemenakan. Hal ini berawal dari lahirnya UU Desa tahun 2014. Tentu jelas apa yang telah dilakukan dalam usaha ini, perjuangan murni serta usulan murni dari masyarakat Tiga Lorong yang telah berusaha dari akar paling bawah sampai ke pucuk paling atas.

Ekmal Hamdi (36 tahun) sekretaris desa Baturijal Hulu sangat mendukung desanya ditetapkan sebagai desa adat. Ia akan melengkapi persyaratan desa adat jika ia mengetahui prosedurnya. Dalam berbagai pendapat dengan pihak LAM Kabupaten dan LAM Riau, terutama dokumentasi penting tembo Tiga Lorong kawasan hukum Tiga Lorong memiliki tanah ulayat, hak masyarakat adat itu perlu dikembalikan kepada masyarakat (Ishaq \& Minarsih, 2003). Permasalahan ini juga diperkuat dengan adanya pasal 103, UU no. 6 tahun 2014 bahwa salah satu kewenangan desa adat adalah kembali diberikan pengaturan dan pengurusan tanah ulayat.

Sementara itu, Yusri (44 tahun) sebagai sekretaris camat Peranap berpendapat, bahwa penetapan desa adat dapat mengancam jabatan politik kepala desa yang sekarang sedang 
berjalan disebabkan bertukar menjadi penghulu adat. Hal ini juga perlu diteliti lagi bagaimana pengaturan bentuk struktur institusi desa adat. Pada tahun 2018, provinsi Riau telah menerbitkan Peraturan Daerah No. 14 tahun 2018 bahwa daerah telah mengakui masyarakat hukum adat dan lembaga adat sebagai lembaga yang mengurusi berbagai persoalan yang berkaitan dengan adat lokal.

\subsection{Tidak Ada Tindak Lanjut Dari Pemerintah Kabupaten}

Proses penetapan desa menjadi desa adat, dapat mengikuti dan merujuk Peraturan Pemerintah No. 43 tahun 2014 tentang peraturan pelaksanaan undang-undang No. 6 tahun 2014. Pasal 30 Peraturan Pemerintah ini menjelaskan bahwa prosedur atau mekanisme untuk menetapkan desa menjadi desa adat adalah adanya proses pengidentifikasian dan pengkajian lebih lanjut yang dilakukan oleh pemerintah daerah kabupaten bersama majelis adat atau lembaga yang sejenis. Dalam persoalan ini, pemerintah kabupaten tidak melakukan mekanisme penetapan desa adat secara sendiri-sendiri melainkan harus melakukan kerjasama dengan lembaga adat. Informasi data berkaitan calon desa-desa yang mempunyai peluang menjadi desa adat, dapat dijadikan dasar dalam menyusun peraturan daerah penetapan desa adat di Kabupaten. Pada kasus ini, Provinsi Riau mempunyai Lembaga Adat Melayu (LAM) Riau yang telah berdiri semenjak tahun 1970. Lembaga ini yang bekerjasama dengan pemerintah daerah untuk membantu menyusun materi Ranperda. Untuk mengetahui bagaimana proses dalam kerjasama pemerintah daerah dengan Lembaga Adat Melayu Riau dapat dilihat hasil wawancara dengan kepala bidang Dinas Pemerintah Desa Kabupaten Indragiri Hulu yaitu Kamaruzaman (47 tahun).

Data wawancara bersama kepala bidang Dinas Pemerintah Desa Kabupaten Indragiri Hulu telah membenarkan bahwa benar Lembaga Adat Melayu Riau di tingkat kabupaten Indragiri Hulu telah turun untuk melakukan inventarisasi desa, namun tidak ada usulan resmi dari desa melalui pemerintah kecamatan dan juga Dinas Pemerintah Desa tidak menerima bahan materi. Sementara itu, wawancara bersama Zulkifli Gani (63 tahun) dan Alifahmi Aziz (58 tahun) sebagai Ketua (Tokoh BudayaIndragiri Hulu) dan sekretaris LAM Riau menyatakan telah melakukan rapat hingga di tingkat Lembaga Adat Melayu Provinsi Riau serta sudah menyampaikan beberapa desa yang memenuhi kriteria untuk dijadikan sebagai desa adat kepada bupati Indragiri Hulu. Beberapa desa di Kecamatan Peranap diantaranya adalah yang termasuk ke dalam desa yang memenuhi syarat. Pada suatu pertemuan dengan pemerintah daerah, semua pihak telah sepakat untuk membuat tim identifikasi desa adat. Namun, kedua informan menyatakan hal yang sama, bahwa pemerintah daerah tidak mengusulkan Lembaga Adat Melayu Riau Kabupaten membantu memperjuang mengurus desa adat.

Jadi, usaha untuk menetapkan beberapa desa di Kabupaten Indragiri Hulu berhenti sampai di tingkat LAMR Kabupaten.Lembaga Adat Melayu Riau Kabupaten adalah lembaga yang hanya memfasilitasi pemerintah daerah untuk mengkaji adat istiadat di desa dan juga menstimulasi pemerintah daerah untuk segera menerbitkan peraturan daerah desa adat. Walaupun begitu, LAMR Kabupaten akan tetap komitmen dalam memperjuangkan desa adat.

\section{Diskusi}

Penelitian ini berawal dari munculnya UU Desa No. 6 pada tahun 2014.Dalam salah satu bagian undang-undang tersebut terdapat bagian khusus pengaturan desa adat. Di Provinsi Riau sebenarnya beberapa kabupaten cukup cepat dalam menanggapi undang-undang tersebut terutama pihak Lembaga Adat Melayu Riau. Lembaga ini kemudian mendesak Gubernur Riau untuk proaktif dalam proses mewujudkan desa adat. LAM Riau kemudian mensosialisasikan UU Desa ke berbagai Kabupaten/Kota di Riau. Namun, kemudian hingga di batas akhir sosialisasi yang ditetapkan pemerintah pusat, ada dua kabupaten yang siap dengan Peraturan daerahnya, yakni Kabupaten Siak dan Kabupaten Rokan Hulu. Merujuk penelitian terdahulu oleh Alkadafi et al., (2019) dan Suganda \& Amin, (2016), bahwa dalam penetapan desa adat di dua kabupaten tersebut banyak mengalami dinamika dalam proses politik pada proses penetapannya seperti tanpa melalui penelitian yang panjang, pelanggaran secara administrasi, penolakan oleh kepala desa sebagai pemegang jabatan politik di peringkat desa, tanpa melalui proses penjaringan berdasarkan kriteria tertentu, keperluan regulasi dalam pemerintahan desa adat dan penguatan lembaga adat di masing-masing desa. Hasil penelitian ini melengkapi dan menjawab persoalan penetapan desa adat setiap kabupaten yang ada di Provinsi Riau dan sudah diperoleh pada penelitian sebelumnya.

Hasil penelitian ini menemukan empat hal yang menjadi tantangan pemerintah daerah dalam usaha mendirikan desa adat. Persoalan pertama adalah keterbatasan peluang dan 
kesempatan dalam penetapan desa adat. Persoalan ini juga menjadi jawaban serta penyebab utama dalam proses penetapan desa adat yang tidak melalui proses penelitian yang akurat, longgarnya penyeleksian, hingga mengabaikan prosedur yang sudah ada dan terdapat dalam UU Desa. Persoalan kedua adalah tidak mengarus utamakan sosialisasi pedoman penetapan desa adat kepada masyarakat, pemangku adat, dan pihak terkait. Tokoh masyarakat Riau bahkan memprotes keras kebijakan pemerintah pusat yang membatasi peluang pengurusan desa adat. Padahal sebenarnya untuk mencapai keadilan yang setinggi-tingginya, masyarakat harus diberi pemahaman yang baik yang berkaitan standar operasional prosedur terhadap produk hukum. Semakin ramai masyarakat yang mengetahui peraturan perundangundangan tentang penetapan desa adat ini, maka semakin ramai pula umpan balik (feedback) yang diberikan kepada UU tersebut semenjak diterbitkan. Menurut Asshidiqie, proses penyebarluasan undang-undang ke tengah publik adalah Promulgation of Law (Wijaya, Anggraeni, \& Bachri, 2011). Tujuannya adalah pemahaman yang sampai berkenaan materi dan maksud daripada undang-undang tersebut. Hal ini tentu perlu didukung seperti infrastruktur internet yang memadai untuk memaksimalkan penyebarluasan UU hingga kepada peringkat pemerintahan paling bawah yaitu pemerintah desa. Seharusnya penyebarluasan dilakukan ketika UU masih dalam bentuk rancangan undang-undang. Artinya, masyarakat di Indonesia masih ramai yang tidak tahu proses perancangan UU tersebut dan hanya tahu ketika UU telah jadi dan diterbitkan.

Sosialisasi UU memberikan kontribusi yang tinggi terhadap kesadaran masyarakat terhadap informasi yang terkandung dalam UU tersebut. Perlu peningkatan dalam penyebarluasan (sosialisasi) peraturan perundang-undangan untuk meningkatkan pemahaman serta memberi pengetahuan hukum kepada masyarakat. Berbagai jenis media yang dapat digunakan untuk menyampaikan informasi dalam UU secara maksimal yaitu jenis media cetak, media elektronik dan media komunikasi tatap muka langsung.Media komunikasi tatap muka langsung sangat sesuai dengan sosial-ekonomi karena bersifat responsif kepada masyarakat dan juga tidak memerlukan infrastruktur yang mahal seperti internet. Pada negara Indonesia, perlu mengoptimalkan cara penyebarluasan lewat media cetak dan tatap muka karena media elektronik seperti internet mempunyai kelemahan dalam hal infrastruktur yang masih mahal dalam implementasinya. Hal ini disebabkan tidak meratanya infrastruktur di berbagai daerah di Indonesia.

Permasalahan ketiga adalah berkaitan dengan pemahaman pihak penyelenggara pemerintah kecamatan yang menilai kearifan lokal dan adat istiadat bukan hal utama dan penting dalam kehidupan sosial-ekonomi masyarakat. Pada kasus ini, terlihat pemerintah kecamatan tidak aspiratif dan memiliki pengetahuan yang memadai terhadap sendi-sendi kehidupan masyarakat yang dipimpinnya. Kasus ini selain berhubungan dengan otoritas pendidikan pemimpin kecamatan juga memperpanjang konflik bupati dengan Lembaga Adat Melayu Kabupaten. Padahal, pihak kecamatan menjadi perpanjangan tangan masyarakat desa dalam menyampaikan usulan kepada pemerintah di atasnya. Pihak legislatif juga tidak mengambil inisiatif terhadap usulan pendirian desa adat ini. Pemahaman secara antropologis misalnya, bahwa masyarakat hukum adat telah lama melekat hak-hak komunal yang sudah terbentuk sejak lama sebelum negara ini terbentuk tidak dihayati dengan baik. Dalam berbagai dokumen, fenomena, dan fakta di lapangan memperlihatkan hak-hak masyarakat hukum adat diabaikan, tergerus oleh penguasaan tanah oleh pihak perusahaan. Pranata sosial masih berlaku, seperti tenganai rumah, tenganai besar, dan menti. Adalah sangat penting masyarakat menjalankan cara-cara tradisional dalam kehidupan sehari-hari. Beberapa sumber ekonomi masyarakat masih bergantung kepada sumber daya alam (Zainal Abidin \& Ta Wee, 2013). Dalam kehidupan masyarakat hukum adat, desa adat memegang peranan penting dalam kehidupan tradisional adat-istiadat yang bersifat komunal dan berkaitan erat dengan persoalan magis serta spiritualisme (Hadi, 2017).

Pada masa sekarang, pengakuan negara terhadap masyarakat hukum adat beserta hakhaknya sudah tersebar dalam berbagai peraturan perundang-undangan seperti UndangUndang Pengelolaan Agraria (UUPA), UndangUndang Kehutanan No.41/1999, UndangUndang Pengelolaan Pesisir dan Pulau-Pulau Kecil No. 27/2007, UndangUndang Perkebunan No. 39/2014, Peraturan Menteri Dalam Negeri tentang Pedoman Pengakuan Perlindungan Masyarakat Hukum Adat No. 52/2014, dan Peraturan Menteri Agraria dan Tata Ruang Tentang Penetapan Hak Komunal Atas Tanah Masyarakat Hukum Adat No. 9/2015 (Nurhidayah, 2017).

Di samping itu, perjuangan yang telah dilakukan Aliansi Masyarakat Adat Nusantara (AMAN) sebagai organisasi masyarakat telah mampu memulihkan kawasan-kawasan adat 
dengan mendesak keluarnya keputusan Mahkamah Konstitusi No. 35 yang memisahkan hutan adat di dalam kategori hutan negara. Justru, ini menjadikan masyarakat hukum adat sebagai subjek hukum, pemegang hak yang berkuasa di kawasan adatnya (Arsyad, Sunito, \& Kartodiharjo, 2016). Ini bermaksud bahwa masyarakat hukum adat sebagai masyarakat yang mandiri dan independen dapat mengatur dirinya sendiri. Hukum adat yang menjadi panutan dalam kehidupan sehari-hari masyarakat hukum adat juga dapat bersumber secara tidak tertulis dan berbeda dengan hukum negara. Unsur hukum adat mempunyai unsur sejarah dan realisme hukum dan berkaitan erat dengan masa lalu hingga ke masa depan (Sulaiman, Adli, \& Mansur, 2019).

Permasalahan keempat adalah tidak ada kemajuan kelanjutan di peringkat pemerintah kabupaten. Menurut Buana (2017) dalam realitanya sangat sulit bagi pemerintah daerah untuk berusaha secara ikhlas mengakui masyarakat hukum adat. Sementara yang terjadi pada kasus pemerintah Jambi sebelum adanya UU Desa no. 6 tahun 2014, sudah menerbitkan beberapa produk hukum dikabupaten sebagai pemberian penghormatan kepada masyarakat hukum adat seperti surat Keputusan Bupati tentang Penetapan Lokasi Hutan Adat, surat Keputusan Bupati Tentang Penetapan Hutan Adat Desa, dan Peraturan Daerah Kabupaten Tentang Masyarakat Hukum Adat (Radjab, 2015). Semua produk hukum yang sudah dikeluarkan oleh pemerintah daerah tersebut juga merupakan ketegasan dari putusan Mahkamah Konstitusi No. 35/2011 sebagai perlindungan terhadap hutan masyarakat hukum adat (Salam, 2016). Selain di Provinsi Jambi, di Provinsi Bali juga sudah lama menerapkan desa yang unik dengan dualismenya yaitu desa adat yang biasa dikenal pakraman dan desa dinas yang dikenal dharma negara. Keduanya berjalan secara seimbang dan harmonis semenjak penerapannya hingga sekarang dan juga mendapat pengecualian dari UU Desa No. 6 tahun 2014 karena tidak harus memilih salah satu jenis desa dan karena memang selama ini sudah selaras (Mulyanto, 2015).

Tantangan lain juga terjadi pada desa lainnya di Indonesia seperti jumlah penduduk yang tidak mencukupi, penolakan program pemerintah yang bertentangan dengan kehidupan sosial-budaya masyarakat dan juga sikap perbuatan pemerintah daerah untuk menerbitkan peraturan daerah masyarakat hukum adat. Zakaria menjelaskan ada 3 motivasi untuk mendorong percepatan penerbitan UU tersebut yaitu komitmen pemerintah daerah, kapasitas pemerintah daerah, dan memerlukan kontrol sosial hingga realisasinya (Illiyani, 2018). Kementerian Dalam Negeri juga berperan dalam merangsang pemerintah daerah supaya untuk segera menerbitkan peraturan daerah penetapan desa adat. Melalui Peraturan Menteri Dalam Negeri No.52 tahun 2014 tentang pengakuan dan perlindungan masyarakat hukum adat, memperlihatkan kuasa seluas-luasnya terletak pada bupati sebagai pemerintah daerah. Pemerintah daerah sebagai perpanjangan tangan negara mempunyai otoritas penuh dalam mengembalikan hak-hak masyarakat hukum adat dan menjaga eksistensinya (Subroto, 2019). Perlu adanya peraturan daerah sebagai dasar legalitas hukum. Ini juga diperlukan untuk menambah kapasitas dalam menyelesaikan konflik-konflik yang berkaitan tanah ulayat dan semua pengurusan berhubungan dengan sumber daya alam di kawasan sekitarnya. Upaya pengakuan ini juga berguna untuk menghindari degradasi karena pengaruh budaya luar, eksploitasi sumber daya alam dan jual-beli tanah kepada penduduk pendatang (Nurhidayah, 2017). Dan tentu saja memberikan aksesibilitas yang lebih luas bagi penduduk lokal pada peluang usaha alternatif sejalan dengan kehadiran perusahaan.

\section{Kesimpulan}

Permasalahan pengakuan masyarakat hukum adat dan desa adat di Riau masih menjadi perbincangan di kalangan akademik karena hak-hak yang melekat secara hakikat dalam masyarakat dan perlu dilindungi dari pengaruh luar. Penelitian ini menemukan beberapa faktor yang menjadi tantangan di pemerintah daerah yaitu, pertama, peluang penetapan desa adat dilakukan dalam masa yang singkat. Ini menjadi sebab utama dalam masalah proses penetapan desa adat di daerah lain seperti tidak melakukan penelitian mendalam dan melewati beberapa prosedur mekanisme dalam undang-undang. Kedua, tidak mengutamakan sosialisasi pedoman penetapan desa adat. Sosialisasi UU Desa harus dilakukan untuk memastikan informasi dan pemahaman sampai kepada masyarakat secara tepat. Jika ada masyarakat yang tidak mengetahui satu bagian dari isi UU Desa maka pemerintah telah gagal dalam melaksanakan sosialisasi. Justru satu indikator keberhasilan implementasi peraturan perundang-undangan dilihat dariperanan pemerintah dalam usaha mensosialisasikan undang-undang. Ketiga, pemahaman penyelenggaran pemerintahan, terutama kecamatan yang kontra produktif terhadap UU Desa, yakni 
kearifan lokal dianggap tidak penting bagi masyarakat. Padahal jika sikap dan pengetahuan yang baik terhadap kebutuhan masyarakat maka pemerintah kecamatan memiliki peranan yang penting untuk memperjuangkan kepada pemerintah kabupaten. Keempat, tidak ada progres lanjutan dari pemerintah kabupaten untuk menetapkan peraturan daerah desa adat. Hal ini adanya sikap tidak sejalan pemerintah di daerah dengan lembaga adat, dan tidak sejalannya dengan pihak legislatif. Sementara pengakuan masyarakat hukum adat dalam penetapan desa adat memerlukan peraturan daerah untuk menetapkannya. Bupati sebagai otoritas yang berkuasa penuh kepada daerahnya perlu memahami pentingnya menjaga hak ulayat seperti hutan adat sebagai sumber utama dalam pembangunan ekonomi masyarakat yang terikat oleh hukum adat. Sudah menjadi kewajiban pemerintah daerah untuk bertanggung jawab dan melindungi aspek-aspek adat-istiadat masyarakat yang masih terkandung dan bertahan hingga saat ini.

Melihat berbagai faktor yang telah diungkapkan, bahwa implikasi hasil kajian ini adalah adanya indikasi kekeliruan dalam memahami amanah UU Desa no. 6 tahun 2014 tersebut. Amanah itu telah tertulis pada UU Desa serta juga dalam Peraturan menteri dalam negeri bahwa indikatornya adalah pemerintah daerah tidak melakukan upaya yang optimal seperti bersinergi dengan pemangku adat yang bernaung dengan lembaga adat, dalam kasus ini Lembaga Adat Melayu Riau Kabupaten. Sesuai UU Desa, sosialisasi memang sudah dilakukan namun pemerintah daerah tidak mengoptimalkannya, terutama khusus berkenaan prosedur penetapan desa adat sehingga tidak menyiapkan infrastruktur untuk menginventarisir desa yang layak dijadikan sebagai desa adat. Hal ini tentu menjadikan pemerintah daerah gagal dalam mengartikulasikan kembali amanah berkenaan desa adat dalam UUdesa tersebut.

\section{Ucapan Terima Kasih}

Terima kasih saya ucapkan kepada Dr. Mimi Hanida Abdul Mutalib yang telah membantu penulis dalam perihal pendanaan publikasi dan kontribusi terhadap gagasan-gagasan dalam penulisan jurnal penelitian ini. Terakhir, saya juga ucapkan terima kasih kepada Dr. Elmustian Rahman yang telah membantu penulis memperbaiki tata bahasa yang digunakan dalam artikel ini dan juga telah membantu memberikan gagasan-gagasan besar tentang pemahaman masyarakat hukum adat di Riau serta mengkritisasi serangkaian peristiwa mengenai proses penetapan desa adat di Indragiri Hulu.

\section{Pendanaan}

Penelitian ini didanai oleh Dr. Mimi Hanida Abdul Mutalib.

\section{Daftar Pustaka}

Agus, A. A. (2017). Eksistensi Masyarakat Adat dalam Kerangka Negara Hukum di Indonesia. Jurnal Sosialisasi Pendidikan Sosiologi-FIS UNM, 4(1), 5-15.

Alhojailan, M. I. (2012). Thematic Analysis: A Critical Review of Its Process and Evaluation. West East Journal of Social Sciences, 1(1), 39-47.

Alkadafi, M., Rusdi, Nasution, F. R. A., \& April, M. (2019). Kebijakan Penetapan Pemerintahan Kampung Adat di Kabupaten Siak Provinsi Riau. Jurnal El-Riyasah, 1O(1), 1-20. https://doi.org/10.24014/jel.v10i1.7445

Arsyad, I., Sunito, S., \& Kartodiharjo, H. (2016). Analisis Aktor dalam Pembentukan Kebijakan Pengakuan Masyarakat Hukum Adat Pasca Putusan MK 35 (Studi atas Peran AMAN dan Jaringannya dalam Mendorong Pengakuan Masyarakat Hukum Adat Melalui UU Desa dan RUU PPMHA. Sodality: Jurnal Sosiologi Pedesaan, 4(3), 224-232. https://doi.org/10.22500/sodality.v4i3.14431

Buana, M. S. (2017). Hak Masyarakat Adat atas Sumber Daya Alam: antara Doktrin Pembangunan dan Hukum Hak Asasi Manusia Internasional. Padjadjaran Jurnal Ilmu Hukum, 4(2), 341-361. https://doi.org/10.22304/pjih.v4n2.a7

Creswell, J. W. (2009). Research Design: Qualitative, Quantitative and Mixed Method Approaches (3rd ed.). Los Angeles: SAGE Publications.

Farakhiyah, R., \& Irfan, M. (2019). Eksistensi Masyarakat Adat Tergerus oleh Kebutuhan Zaman: Studi Analisis Konflik Masyarakat Adat Sunda Wiwitan di Kuningan yang Terusir dari Tanah Adatnya Sendiri dengan Teori Identitas. Jurnal Kolaborasi Resolusi Konflik, 1(1), 44-54. https://doi.org/10.24198/jkrk.v1i1.20892

Fazar. (2014, October). Pemkab Indragiri Hulu akan Bentuk Desa Adat. Media Center Riau.

Fusch, P., Fusch, G. E., \& Ness, L. R. (2018). Denzin's Paradigm Shift: Revisiting 
Triangulation in Qualitative Research. Journal of Social Change, 1O(1), 19-32. https://doi.org/10.5590/josc.2018.10.1.02

Hadi, A. (2017). Desa Adat dalam Sistem Ketatanegaraan Republik Indonesia sebagai Implikasi Hukum setelah berlakunya UU No. 6 Tahun 2014 Tentang Desa. DiH Jurnal Ilmu Hukum, 13(26), 162-174. https://doi.org/10.30996/dih.v0i0.1580

Hamamah, F., \& Sarip. (2019). Optimalisasi Lembaga Adat Desa Meneguhkan Konstitusionalisme. PAGARUYUANG Law Journal, 2(2), 163-180.

Hamdi, S. (2018). Eksistensi Peran Majelis Adat Aceh dalam Mensosialisasikan Nilai-Nilai Pendidikan Islam di Wilayah Barat-Selatan Aceh. Ar-Raniry, International Journal of Islamic Studies, 5(1), 115-137. https://doi.org/10.20859/jar.v5i1.196

Heriyanto, H. (2018). Thematic Analysis sebagai Metode Menganalisa Data untuk Penelitian Kualitatif. ANUVA, 2(3), 317-324. https://doi.org/10.14710/anuva.2.3.317-324

Idris, Z., Apriani, D., \& Erlina. (2019). Towards Legitimate Indigenous People and Problemetical in Indonesia. Asian Journal of Environment, History and Heritage, 3(1), $165-174$.

Illiyani, M. (2018). Thinking Intellectually, Knowing Globally, and Act Locally: The Prospect of Kampung Naga as An Indigenous Village. Jurnal Masyarakat \& Budaya, 20(1), 1530. https://doi.org/10.14203/jmb.v20i1.588

Ishaq, I., \& Minarsih, M. D. (2003). Tiga Lorong dalam Sejarah Kerajaan Indragiri (1735 1765). Pekanbaru: UNRI Press.

Jayus, J. A. (2019). Eksistensi Pewarisan Hukum Adat Batak. Jurnal Yudisial, 12(2), 235253. https://doi.org/10.29123/jy.v12i2.384

Kalembang, E. (2018). Tanah Ulayat Sebagai Simbol Eksistensi Adat-Istiadat: Studi Kasus tentang Konflik Tanah Ulayat di Perbatasan Republik Indonesia (RI) dan Republik Demokratik Timor Leste (RDTL) Segmen Bijael Sunan/Oelnasi. Sabda, 13(1), 44-58. https://doi.org/10.1051/matecconf/201712107005

Mohajan, H. K. (2018). Munich Personal RePEc Archive Qualitative Research Methodology in Social Sciences and Related Subjects. Journal of Economic Development, Environment and People, 7(1), 23-48.

Mulyanto. (2015). Keberlakuan UU No. 6 Tahun 2014 Tentang Desa di Bali dalam Perspektif $\begin{array}{llll}\text { Sosiologi Hukum. MIMBAR HUKUM, 27(3), 418-431. } & \text {. }\end{array}$ https://doi.org/10.22146/jmh.15880

Noor, R. S. (2018). Upaya Perlindungan Hukum Terhadap Eksistensi Masyarakat Hukum Adat Di Kalimantan Tengah. Morality: Jurnal Ilmu Hukum, 4(2), 115-131.

Nurhidayah, L. (2017). Pengelolaan SDA dan Hak-Hak Masyarakat Adat: Studi Kasus Enggano (Natural Resources Management and Adat Community Rights: Enggano Case

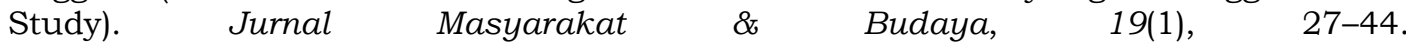
https:// doi.org/10.14203/jmb.v19i1.486

Pohan, M. N. (2018). Hukum Adat Sumatera Utara dalam Yurisprudensi di Indonesia. Doktrina: Journal of Law, 1(1), 1-15. https://doi.org/10.31289/doktrina.v1i1.1607

Putri, E. T., Ramadhan, T. A., Sandya, S. N., Fazriyah, D. M. N., \& Maharani, P. S. (2019). Eksistensi Lamin Adat Pemung Tawai Sebagai Identitas Sosial Masyarakat Dayak Kenyah. Psikostudia: Jurnal Psikologi, 6(2), 58-69. https://doi.org/10.30872/psikostudia.v6i2.2377

Radjab, D. (2015). Peluang Pembentukan Desa Adat di Provinsi Jambi. Jurnal Ilmu Hukum, $6(2), 1-11$.

Rahman. (2018). Eksistensi Hukum Pidana Adat Melayu Jambi dalam Sistem Peradilan Pidana Indonesia. Jurnal Yuridis UNAJA, 1(1), 1-14.

Rahman, E., Azhar, A., \& Rohana, S. (2012). Ensiklopedia Kebudayaan Melayu Riau. Pekanbaru: Pusat Penelitian dan Kebudayaan dan Kemasyarakatan, Universitas Riau.

Rahman, E., Syam, J., \& Mardan, M. (2013). Tiga Lorong: Teguh Berdiri di Tengah Persimpangan Riuh Ramai. Pekanbaru: UNRI Press.

Rahman, F. (2018). Eksistensi Peradilan Adat dalam Peraturan Perundangan-Undangan di Indonesia: Melacak Berlakunya kembali Peradilan Adat di Indonesia dan Relevansinya bagi Upaya Pembangunan Hukum Nasional. Jurnal Hukum Samudra Keadilan, 13(2), 321-336. https://doi.org/10.33059/jhsk.v13i2.1066

Salam, S. (2016). Perlindungan Hukum Masyarakat Hukum Adat Atas Hutan Adat. Jurnal Hukum Novelty, 7(2), 209. https://doi.org/10.26555/novelty.v7i2.a5468

Salim, H. M. (2016). Adat Sebagai Budaya Kearifan Lokal Untuk Memperkuat Eksistensi Adat Ke Depan. Al Daulah: Jurnal Hukum Pidana Dan Ketatanegaraan, 5(2), 244-255. 
https://doi.org/10.24252/ad.v5i2.4845

Subroto, A. (2019). Peran Negara Dalam Menjaga Eksistensi Masyarakat Hukum Adat. YURISKA: Jurnal Ilmiah Hukum, 11(1), 59-73. https://doi.org/10.24903/yrs.v11i1.457

Suganda, H., \& Amin, R. M. (2016). Dinamika Politik Persetujuan Bersama Tentang Penetapan Desa Adat di Kabupaten Rokan Hulu Tahun 2014. Jurnal Ilmu Pemerintahan Nakhoda, 15(25), 38-50. https://doi.org/10.35967/jipn.v15i25.3850

Sulaiman, Adli, M., \& Mansur, T. M. (2019). Ketidakteraturan Hukum Pengakuan dan Perlindungan Masyarakat Hukum Adat di Indonesia. Law Reform, 15(1), 12-24. https://doi.org/10.14710/lr.v15i1.23352

Supian, Fatonah, \& Defrianti, D. (2018). Eksistensi dan penerapan hukum adat melayu di kota jambi. Titian: Jurnal Ilmu Humaniora, 02(02), 341-364.

Taufiqurakhman. (2014). Kebijakan Publik: Pendelegasian Tanggung Jawab Negara kepada Presiden selaku Penyelenggara Pemerintahan. Jakarta: Fakultas Ilmu Sosial dan Ilmu Politik Universitas Moestopo Beragama (Pers).

Warjiyati, S. (2018). Eksistensi Hukum Adat Dalam Penyelesaian Konflik Pada Daerah Otonom. Ahkam: Jurnal Hukum Islam, 6(2), 389-410. https://doi.org/10.21274/ahkam.2018.6.2.389-410

Wiguna, M. O. C. (2016). Pengaruh Eksistensi Masyarakat Hukum Adat terhadap Penguasaan Tanah Prabumian berdasarkan Konsepsi Komunalistik Religius di Bali. Jurnal Hukum Novelty, 7(2), 182-195.

Wijaya, E., Anggraeni, R., \& Bachri, R. (2011). Desa Digital: Peluang untuk Mengoptimalkan Penyebarluasan Peraturan Perundang-undangan di Indonesia. Jurnal Dinamika Hukum, 13(1), 75-88. https://doi.org/10.20884/1.jdh.2013.13.1.158

Winarno, B. (2016). Kebijakan Publik Era Globalisasi. Yogyakarta: CAPS (Center of Academic Publishing Service).

Yeasmin, S., \& Rahman, K. F. (2012). "Triangulation" Research Method as the Tool of Social Science Research. BUP Journal, 1(1), 154-163.

Zainal Abidin, Z. Z., \& Ta Wee, S. (2013). Isu konflik tanah adat bagi Orang Asli di Malaysia. In Persidangan Kebangsaan Geografi dan Alam Sekitar Kali Ke 4 (pp. 577-583). Perak: Universiti Pendidikan Sultan Idris. 